\title{
CONEXÕES ESPIRITUAIS COM A MÃE TERRA: PLENITUDE HUMANA MANIFESTADA PELO XAMANISMO
}

\author{
SPIRITUAL CONNECTIONS WITH MOTHER NATURE: \\ HUMAN WHOLENESS UNVEILED THROUGH SHAMANISM
}

Eraldo Medeiros COSTA-NETO (Tapicha Ka'aguy Jára ${ }^{1}$ )

\section{RESUMO}

Submitted: 29/08/2020; Accepted: 18/09/2020

Surgidas no Paleolítico com grupos de coletores-caçadores, as práticas xamânicas (re)surgem e se popularizam no contexto da atual sociedade "pós-moderna", em que um número cada vez maior de pessoas está construindo suas próprias relações espirituais com a Terra, com outros povos e culturas e com outros seres com os quais se partilha o ambiente. A resposta às crises ecológica e civilizatória requer uma profunda mudança em nossas ações diárias, as quais devem brotar de um profundo sentimento de Amor, Harmonia e Bondade.

Palavras-chave: Interconectividade, Unicidade; Valores e práticas espirituais; Bioética

\section{ABSTRACT}

Emerging in the Paleolithic with groups of hunter-gatherers, shamanic practices (re)appear and become popular in the context of today's "postmodern" society, in which an increasing number of people are building their own spiritual relationships with the Earth, with other peoples and cultures, and with other beings with whom the environment is shared. Responding to ecological and civilizing crises requires a profound change in our daily actions, which must come from a deep feeling of Love, Harmony and Kindness.

Keywords: Interconnectedness; Oneness; Spiritual values and practices; Bioethics

\section{Porã-Hei das Quatro Direções ${ }^{2}$}

Sagrado Senhor que tem muitos nomes

em inúmeras tradições, línguas, culturas!

Que se manifesta pelo fogo do sol que vem do Leste,

Pelas águas que descem do Sul,

Pela terra que germina no Oeste,

E pelo sopro que se recolhe ao Norte;

Eu te saúdo e reverencio e agradeço-lhe pela vida

saudável e harmoniosa que pulsa em mim!

Meu nariz é o Leste que inspira a luz do seu Sol

e vivifica o meu ser.

Meu ventre é a terra que acolhe a tua luz

Que nutre e germina como o Oeste.

Minhas veias e sangue fluem as águas de um vermelho luminoso, como as águas do Sul.

E minha mente repousa no sopro da vida como o Norte,

Pronto para vir a expressar palavras formosas:

Paz, Saúde, Harmonia e Abundância no dia de hoje!

Extraído do livro O trovão e o vento: um caminho de evolução pelo xamanismo tupi-guarani (WERÁ, 2016).

\footnotetext{
${ }^{1}$ Nome Guarani-Ñandéva recebido durante sessão de coroamento na Aldeia Pirajuí (Paranhus - MS), em 2012, na qual recebi o título honorífico de Cacique Intelectual do povo Guarani-Ñandéva.

${ }^{2}$ Porã Hei significa palavras bonitas.
} 


\section{INTRODUÇÃO}

A crise civilizacional moderna está centrada na dominação humana da natureza, guiada pela ganância do capitalismo e do lucro pelo lucro à custa de vidas humanas, animais, vegetais, degradação ambiental, desertificação, erosão genética, extinção em massa, concentração elevada de gases tóxicos na atmosfera etc. (BOFF, 2005; PECK, 2010; LOVATO et al., 2011). Em um mundo materialista, destituído de significado espiritual, o homem relaciona-se com a vida de forma unicamente pragmática e que exclui o sentido transcendental (CAVALCANTI, 2004). Esta é a visão antropocêntrica, na qual os seres humanos estão situados acima ou fora da natureza, como a fonte de todos os valores, e atribui apenas um valor instrumental, ou de "uso", à natureza (DIAMOND, 2005; NAESS, 2007). Como Fernandes Silva (2020, p. 31) alerta: "Boa parte da sistemática destruição do ambiente caracterizada no século XX e a desordenada difusão de construções de estruturas materiais pelo ser humano tem sua origem no senso de usurpação da natureza e na alienação pela posse da matéria".

A abordagem ecocêntrica, por sua vez (NAESS, 2007), advoga que a vida humana e a consciência humana estão ligadas de modo inerente à vida no planeta (TOLLE, 2007, p. 27). Para evitar o colapso total dos mecanismos que sustentam a vida na Terra, torna-se necessário e urgente que os indivíduos voltem a ter a sensação de pertencimento, de conexidade com o cosmos, ficando claro, desde sempre, que a percepção ecológica é espiritual na sua essência mais profunda (CAPRA, 1996; NAESS, 2007; VAUGHAN-LEE, 2013; KRENAK, 2020). Como salienta Alves (2008, p. 434): “A espiritualidade fomenta no homem um respeito para com os seres vivos e seu ambiente físico. Isso é possível quando se vive intimamente doado pela preservação da biodiversidade. Temos que religar o homem com o Absoluto e a natureza." De fato, em diferentes regiões do mundo onde existe uma sinergia entre cultura e espiritualidade verifica-se um incremento da biodiversidade, como a diversidade in situ de plantas comestíveis (Figura 1) (SHIVA, 2016).

Toda comunidade humana inicia suas atividades e modos de cultura, hábitos, comportamentos e relacionamentos a partir dos ecossistemas onde ela se origina. Por isso não existe nenhuma sociedade humana, por mais complexa e tecnológica que se apresente, que não dependa de uma relação com o que os antigos povos chamavam de Mãe Terra, seja por uma questão de dependência de recursos materiais ou devido às conexões arquetípicas (METZNER, 2002). A espécie humana é "a Terra em seu momento de consciência, de responsabilidade e de amor" (BOFF, 2006, p. 55); daí a estreita relação do ser humano para com a Terra e através da Terra para com todo o Universo. É nesta conexão que devemos buscar a identificação de sua natureza e de sua missão (BOFF, op. cit.).

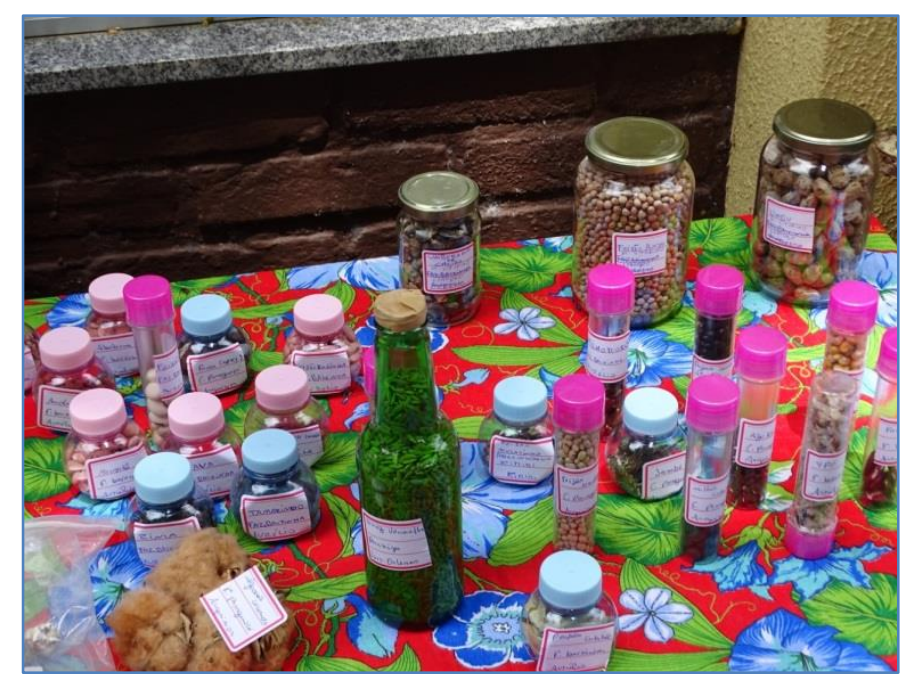

Figura 1. Celebrando a diversidade de sementes, que são um símbolo da vida e representam a divindade em vida. Foto de Aurélio Carvalho (novembro de 2016) durante o festival de sementes crioulas realizado em Feira de Santana, Bahia.

No entanto, parte da humanidade perdeu o laço instintivo com os ritmos e padrões da natureza, ocasionado, entre outras razões, pelo patriarcado, supressão do feminino e avanço do cientificismo; consequentemente, perdeu-se a realidade da magia ou do encantamento do mundo (BOFF, 2015). Com o fortalecimento do modelo patriarcal o elemento feminino, antes venerado e respeitado, passou a ser algo considerado inferior, de menor valia a ser dominado e usufruído (BOFF, op. cit.). A chegada do Cristianismo restringiu a pluralidade das imagens divinas a um pai, reforçando e contribuindo para 
Costa-Neto. Conexões espirituais com a Mãe Terra: plenitude humana manifestada pelo Xamanismo. Ethnoscientia 5, 2020. D.O.I.: 10.22276/ethnoscientia.v5i1.343

legitimar a dominação patriarcal que vigorava entre os gregos e hebreus (CORDOVIL, 2017). Segundo Starhawk (2003), historiadores da religião concordam que nas épocas em que a Grande Mãe era adorada, os seres humanos viviam em maior harmonia com eles mesmos e com a própria força vital. A autora cita que conseguimos vagamente pressentir que houve, há muito tempo, uma unidade primordial, quando uma Mãe Terra e um Pai Espírito desfrutavam de uma união feliz e harmoniosa. Mas esse paraíso foi perdido e, afastados e alienados, fomos forçados a engolir a "amorosa" propaganda de um Pai culpado, porém todo poderoso. A Mãe foi destituída de seus poderes; seus cultos foram dispersos, divididos, abandonados e perseguidos (CAMPBELL, 1997).

Por isso a importância de uma praxis pedagógica pensada e planejada para um novo ativismo ecológico, um que seja ambiental e espiritualmente voltado para trazer a magia da conexão com a natureza de volta à vida humana (COSTA NETO, 2020). Como salienta Montgomery, "Nossa conexão com o espírito começa com nossa conexão com a Terra e os elementos que sustentam a vida. É aqui no mundo natural que nossa conexão com o espírito é facilmente encontrada e fácil de experimentar, porque é intrínseca a terra" (MONTGOMERY, 2008, p. 58-59).

$\mathrm{O}$ ressurgimento de uma atitude respeitosa e reverencial para com a Terra e todas as suas criaturas parece ser uma consequência natural das experiências xamanísticas que vêm sendo rememoradas e experienciadas em todo o mundo (METZNER, 2002; LISBOA, 2012), especialmente a partir do movimento da contracultura na década de 1960. As práticas dos antigos/modernos xamãs, homens e mulheres, visam situar o sujeito no mundo, além de permitir que se tenha uma experiência do sagrado, no sentido de que a reconexão com a natureza passa a fazer parte de um sistema de crenças ecologicamente orientado, motivando o despertar de uma espiritualidade ecológica (para um entendimento sobre ecologia espiritual, sugere-se os textos de ALVES, 2008; CARVALHO e STEIL, 2008). Este retorno do Xamanismo ocidentalizado, denominado neoxamanismo ${ }^{3}$, pode ser visto como uma ampla resposta mundial à degradação do ecossistema e da biosfera: uma tomada de atitude na qual se inserem alguns movimentos fortemente enraizados na ecologia, tais como o ecofeminismo, o biorregionalismo, a ecopsicologia, o neopaganismo, a medicina herbática natural, a agricultura orgânica e outros (MAGNANI, 1999; METZNER, 2002).

$\mathrm{O}$ presente artigo, escrito dentro da perspectiva da ecologia espiritual, trata da plenitude humana manifestada por meio do Xamanismo. Reconheço aqui minhas limitações enquanto pesquisador etnobiólogo lidando com temas caros à antropologia, ciência da religião e psicologia ambiental. Mesmo com brevidade e algumas restrições inevitáveis, acredito informar satisfatoriamente os aspectos essenciais da temática assumida.

\section{As raízes do Xamanismo}

As tradições xamânicas podem datar da época dos primeiros desenhos paleolíticos conhecidos, feitos há cerca de 30.000 anos por nossos ancestrais caçadores (VITEBSKY, 1997). Sítios préhistóricos com arte rupestre incluem equipamentos do xamã, contendo instrumentos de percussão, flautas feitas de ossos de pássaros e marcas de calcanhares indicando danças rituais. A estrutura da caverna simboliza uma jornada para a inconsciência e ao submundo (inframundo), representando a jornada interior do xamã (PUTOVÁ, 2013). De acordo com esta autora, os motivos ilustram toda uma gama de aspectos da prática do xamã, incluindo estados alterados de consciência, rituais, identidade terioantropomórfica (Figura 2) e animais de poder ${ }^{4}$. O uso de cavernas profundas foi considerado um indício de intenção mágica da arte pré-histórica realizada no ventre da terra (COTTRELL, 2008, 2011; RIBEIRO, 2019). Na verdade, os xamãs foram os primeiros mestres do transe e do êxtase (LASCARIZ, 2011). Considerando aspectos de psicologia evolutiva, o Xamanismo foi uma importante evolução da cultura e consciência humanas e criou práticas para expandir as atividades dos antigos seres humanos para a cura ritual e integração do grupo (WINKELMAN, 2007, p. 486).

Os sistemas de crenças xamânicas são encontrados nas vastas regiões da Ásia Central e Sibéria e, em menor grau, na Europa e em outros países, especialmente na América do Norte e do Sul (STUTLEY, 2003; COTTRELL, 2008). Por apresentar uma enorme diversidade geográfica, ecológica,

\footnotetext{
3 Para uma análise critica dos termos "neoxamanismo", "xamanismo urbano" e "xamanismo moderno ocidental", recomenda-se ler as obras de Farley (2010), Lascariz (2011), Kerr (2012), Scuro (2018) e Stern (2019). Considerações epistemológicas e de cunho da Nova Era não são discutidas aqui.

4 "Ossadas de urso pintadas de ocre, encontradas na Bélgica e datadas de 26 mil anos atrás, reforçam a noção de uma protorreligiosidade animal, para além do simples valor utilitário das carcaças” (RIBEIRO, 2019, p. 41).
} 
linguística, étnica e cultural, o Xamanismo não deve ser pensado como uma única religião organizada $^{5}$, mas, devem ser consideradas as diferentes formas existentes de xamanismos, investigando cada tipo segundo as percepções próprias da etnia ou grupo social que as vivenciam e praticam, de acordo com suas crenças e padrões culturais. Não obstante as diferenças culturais, três coisas são compartilhadas por todas as formas de xamanismos:

(1) crença na existência de um mundo de espíritos, principalmente na forma animal, que são capazes de agir sobre os seres humanos. O xamã deve controlar ou cooperar com esses bons e maus espíritos para o benefício de sua comunidade. (2) A indução de transe por canto extático, dança e percussão, quando o espírito do xamã deixa seu corpo e entra no mundo sobrenatural. (3) O xamã trata algumas doenças, geralmente as de natureza psicossomática, além de ajudar os membros do clã a superar suas diversas dificuldades e problemas. (STUTLEY, 2003, p. 2).

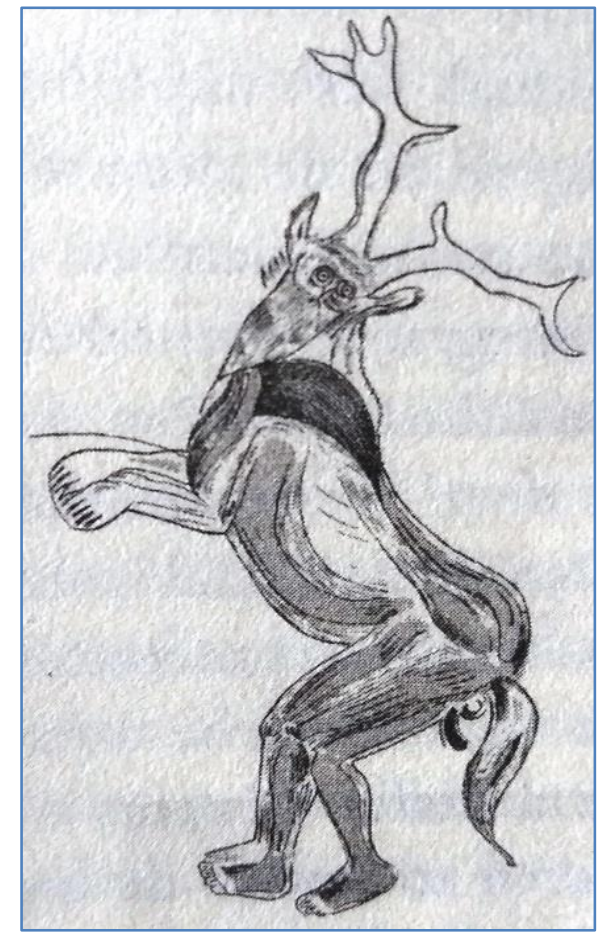

Figure 2. Xamã Feiticeiro, representação terioantropomórfica encontrada na caverna de Les Trois-Frères, Dordogne, França, datada de 14 mil anos atrás. Ilustração extraída de Lascariz (2011) a partir de desenho feito pelo abade Henri Breuil (18771961).

A palavra sâman ou xaman é proveniente do idioma dos Evenk, um pequeno grupo de caçadores e pastores de renas que falam tungus, na Sibéria (VITEBSKY, 1997). Ela significa "aquele que vê no escuro". A raiz da palavra sâman é o verbo sâ, que significa não apenas "ver", mas também "conhecer". De acordo com Lascariz (2011), alguns autores citam que o termo tem uma origem mais humilde, significando "agitado", "excitado". Este autor comenta que muitas outras designações existiam nesse extenso território do círculo polar Ártico e Subártico: bö entre os Buriates e Mongóis; ogun entre os Yakutes; kam entre os Turco-Tártaros; angakok entre os Inuit; tadibey, entre os Samoiedos; alma pelos Yukaghirs. Porém, a expressão mais generalizada ao longo da Sibéria entre a maioria das tribos era odügan (MERCIER, 1987). No sentido mais estrito, xamã refere-se ao praticante que dá consentimento a seu espírito para deixar o corpo, permitindo-se adentrar no mundo superior ou inferior (VITEBSKY, 1997).

\footnotetext{
5 Pesquisas recentes indicam que o Xamanismo representa as primeiras experiências religiosas básicas da humanidade e, portanto, é importante para a compreensão de toda a cultura humana, incluindo as crenças da Idade da Pedra, e para o simbolismo das antigas pinturas rupestres da Eurásia, datando de cerca de $3.000 \mathrm{aC} \mathrm{a}$ cerca de $100 \mathrm{aC}$ (STUTLEY, 2003).
} 
O termo xamã foi utilizado pela primeira vez pelo embaixador do Grão-Duque de Moscou, Evert Ysbrants Ydes, em 1692, para designar os extáticos da Sibéria que os exploradores russos tinham aventurado visitar (LASCARIZ, 2011). De acordo com Lascariz (op. cit.), o primeiro relato publicado sobre um xamã foi feito pelo explorador alemão Nicholas Witsen, em North and East Tartary (1692), que apresentou o primeiro registro desenhado do xamã siberiano com gorro cervídeo, a quem chamou "O Sacerdote do Diabo" (Figura 3). No entanto, o termo xamanismo aparece no chinês escrito desde pelo menos o século XII, referindo-se às práticas religiosas dos "povos bárbaros" que fizeram a corte chinesa recuar durante a Dinastia Jin (KÓSA, 2008 apud STERN, 2019).

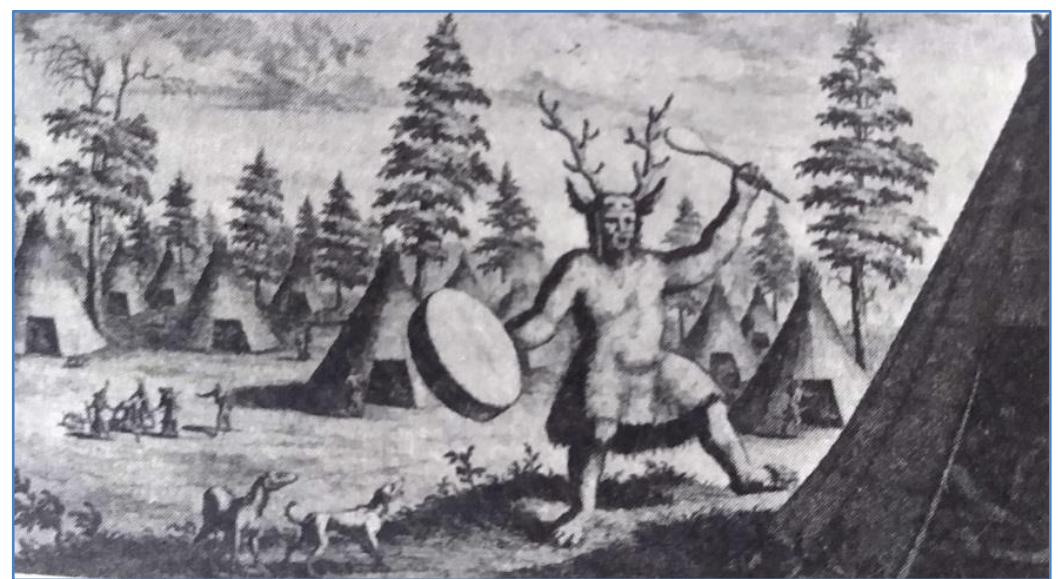

Figura 3. Xamã Tungus, registrado no livro North and East Tartary por Nicholas Witsen, 1785. Ilustração extraída de Lascariz (2011).

Embora a palavra "xamanismo" tenha sido introduzida na academia europeia por Pallinot em 1913 (STERN, 2019), foi Eliade que a celebrizou e generalizou no livro de 1951, intitulado Xamanismo: técnicas arcaicas do êxtase. Fenômenos parecidos foram identificados em outras culturas de caçadores-coletores e as palavras xamã e xamanismo ${ }^{6}$ se tornaram universais para indicar tais pessoas e suas atividades, independente de sua localização geográfica (ZNAMENSKI, 2007). Embora alguns estudiosos tenham questionado a sugestão de Eliade para a universalidade do Xamanismo, a pesquisa transcultural de Winkelman estabeleceu a validade universal do conceito de xamã, bem como as características dos xamãs, particularmente suas diferenças em relação a outros tipos de praticantes mágico-religiosos (WINKELMAN, 1990, 1992). Como salientado por Fotiou (2016, p. 152), o fascínio do Ocidente pelo xamanismo, tanto acadêmico quanto popular, tem oscilado entre extremos. As abordagens para estudar o Xamanismo no passado foram unilaterais, romantizando ou demonizando, enquanto os estudos mais recentes enfocaram de forma mais holística, olhando para os elementos de cura e violência, bem como para o contexto histórico e político.

Atualmente, não existe consenso em relação ao conceito antropológico de xamã (FOTIOU, 2016). Diz-se ser uma espécie de sacerdote, curandeiro, médico, adivinho e conselheiro. De qualquer modo, define-se como um líder espiritual com funções e poderes de natureza ritualista, mágica e religiosa que, por meio do estado de êxtase (estado alterado de consciência), tem a capacidade de contatar com o mundo não-ordinário e com as forças anímicas da natureza (ABALADA, 2009). Xamãs, sacerdotes e sacerdotisas são os guardiões do conhecimento sagrado da vida. Estando ligados ao ritmo e forças da natureza, são capazes de recorrer aos caminhos que unem os mundos visível e invisível, lembrando as pessoas de que as árvores são sagradas e que os animais se comunicam com quem estiver disposto a escutar (ANDREWS, 2013). As práticas xamânicas pretendem ampliar o coração, inspirar o discernimento, a sensibilidade e crescer dentro de cada um tudo aquilo que é essencial, crescer em consciência (KING, 2010).

\footnotetext{
${ }^{6}$ No sistema brasileiro de medicina indígena, os termos pajelança e pajé podem ser tomados como equivalentes aos termos xamanismo e xamã (OLIVEIRA e BORGES, 2010).
} 
Costa-Neto. Conexões espirituais com a Mãe Terra: plenitude humana manifestada pelo Xamanismo. Ethnoscientia 5, 2020. D.O.I.: 10.22276/ethnoscientia.v5i1.343

Como assinala Abalada (2009), o xamã constitui em si próprio a conexão do homem com o Grande Espírito (o Absoluto de quem fala ALVES, 2008). As técnicas milenares e ancestrais para indução de estados alterados de consciência (viagens xamânicas), como o uso do chocalho, do tambor, da flauta, jejuns, exercícios de respiração, ingestão de plantas enteógenas (psicotrópicas; Figura 4), as danças frenéticas (até conseguir o estado de exaustão) e cantos, favorecem processos de autoconhecimento e curas pessoais (MACRAE, 1992). Os seus mistérios xamânicos focalizavam-se nas divindades da fertilidade da terra e das águas, dos poderes da fecundidade e da regeneração, da saúde, do prazer e das boas colheitas. É aqui que encontramos os arquétipos dos deuses primordiais da caça e das manadas de animais, como o Senhor das Feras ou Deus de Chifres, que estão intimamente relacionadas com o Submundo à luz do Xamanismo clássico (JACKSON, 2008, p. 17).

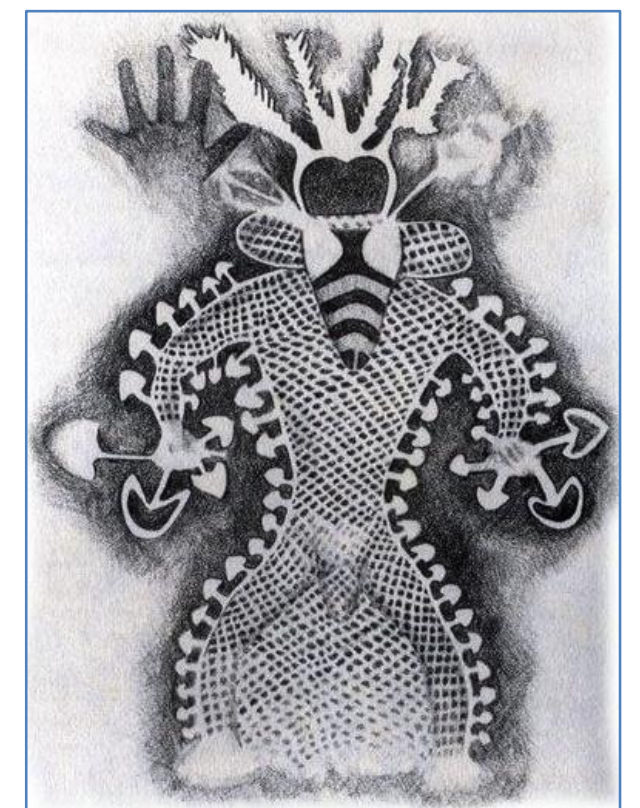

Figura 4. Pintura rupestre que data do final do Neolítico, representando o xamã cogumelo com cara de abelha, encontrada no platô de Tassili-n-Ajjer, deserto do Saara. Desenho de Kat Harrison-McKenna. Extraído de McKenna (1993).

\section{Assim na Terra como no Céu}

O Xamanismo nos ensina que estamos unidos a Terra e toda a vida por meio de nossa interconectividade espiritual. Segundo a Lei Hermética da Correspondência, todas as coisas estão interconectadas e todas são importantes; assim, não se pode separar o físico do espiritual, nem o visível do invisível (ANDREWS, 2013). As culturas indígenas e orientais reconheceram desde muito tempo que a única constante é a mudança e que o princípio de interdependência é essencial para a sobrevivência (ARRIEN, 2015). Assim como a física quântica descreve um campo de energia que conecta toda a vida (CAPRA, 1996), xamãs também falam de uma teia de vida que a tudo conecta (RINPOCHE, 2002; INGERMAN, 2008).

Desse modo, o templo é a própria Natureza. Tudo se torna sagrado na espiritualidade natural (ecológica). O Céu torna-se o Pai, que ensina o caminho das estrelas e das origens ancestrais. A Terra torna-se a Mãe, que ensina os caminhos das relações, das integrações e da evolução na matéria. $O$ grande Avô é o Sol, que ensina a sabedoria dos ciclos e do círculo da vida; a Avó Lua, com sua serenidade, ensina a arte de sonhar e os mistérios que iluminam os caminhos pelas noites da vida. As Árvores e os Vegetais tornam-se o Povo em Pé; as Águas, o Povo das Águas; o Trovão, o Espírito do Trovão; as Pedras, o Povo de Pedra e todos os Animais tornam-se os Irmãos mais jovens, cada um com sua medicina particular. Tudo possui uma energia vital, uma força, um espírito. Tudo se torna sagrado (SAMS, 1993; SOUZA DE PAULA, 2014; MATTIMORE e STAR WOLF, 2018).

No pensamento xamânico, cada elemento do mundo ao nosso redor, seja humano, animal, árvore, rio, cachoeira ou rocha, está imbuído de espíritos, que se relacionam uns com os outros. No livro Ideias para adiar o fim do mundo, o autor e líder indígena Ailton Krenak nos conta a seguinte narrativa: 
"Li uma história de um pesquisador europeu do começo do século XX que estava nos Estados Unidos e chegou a um território dos Hopi, ele tinha pedido que alguém daquela aldeia facilitasse o encontro dele com uma anciã que ele queria entrevistar. Quando foi encontrá-la, ela estava parada perto de uma rocha. O pesquisador ficou esperando, até que falou: 'Ela não vai conversar comigo não?'. Ao que seu facilitador respondeu: 'Ela está conversando com a irmã dela'. 'Mas é uma pedra'. E o camarada disse: 'Qual é o problema?'”. (KRENAK, 2019, p. 17).

Os espíritos são conscientes, muitas vezes antropomórficos (LIVRAGA, 2008), e também podem ser interpretados como representantes das essências subjacentes às aparências superficiais (VITEBSKY, 1997; WESSELMAN, 2006; HARTMANN, 2013). Alguns espíritos cuidam dos recursos de caça e pesca, enquanto outros não têm nenhuma tarefa específica além de assediar aqueles que se aventuram nas profundezas da floresta. Vários seres espirituais habitam árvores; outros adotam a forma humana e punem aqueles que cometem excessos contra a providência da natureza, maltratam os animais, destroem as florestas, ou penetram nos lugares sagrados sem pedir licença ou permissão (STEINHART, 1984; OLIVEIRA e BORGES, 2010). Para obter permissão de acesso aos recursos ou proteção contra acidentes quando se adentra numa floresta ou qualquer outro ambiente natural, fazemse oferendas aos "donos do mato" geralmente na forma de tabaco, pequenas contas, flores, incensos, frutas e grãos diversos (Figura 5). Espíritos guardiões da floresta Amazônica são, por exemplo, Mãe da seringa, Curupira, Cape-lobo, Mãe da piassava e Tapirê-iauara, que ajudam a preservar os recursos da floresta criando zonas de não caça e não pesca (SMITH, 1983). Para os grupos indígenas do Nordeste brasileiro, como os Pankararé que habitam o semiárido do Estado da Bahia, os Encantados (Figura 6) são forças ancestrais, que instituem comunicação, que ajudam, orientam contra abusos durante atividade de caça e unem a comunidade (TOMÁZ e MARQUES, 2019).

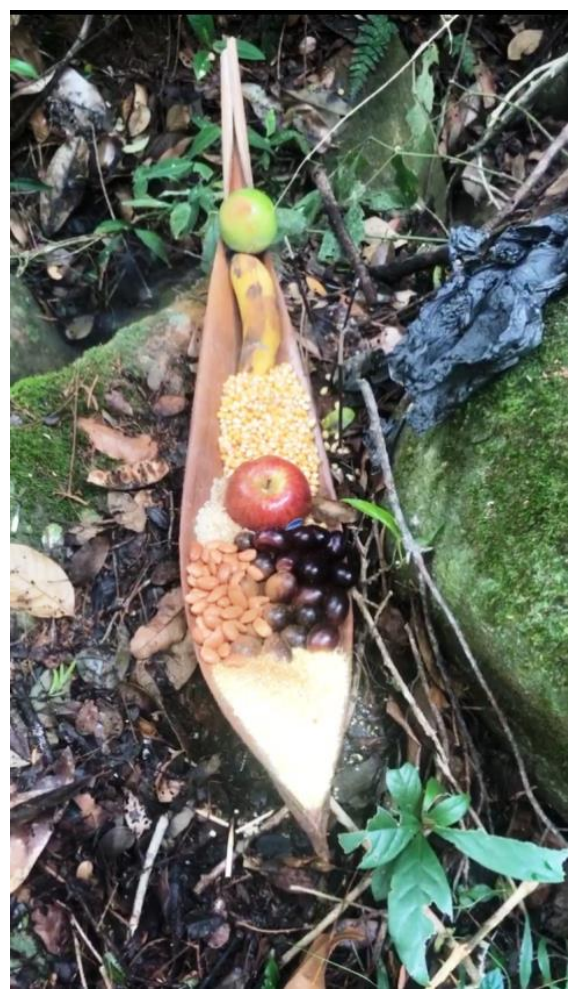

Figura 5. Oferenda aos donos do mato na Serra da Jiboia, Bahia, realização por membros da oficina de construção de tambores xamânicos. Foto do autor (março de 2020).

Um estudo realizado com comunidade de pescadores artesanais no interior do Estado do Piauí, Brasil, mostrou que esses pescadores convivem com diferentes representantes míticos que habitam os ambientes aquáticos, como Mãe d'água, Cabeça de cuia, Muleque d'água, Visage, Piratinga, Sucuiuiu, Luz e Arco-íris (SILVA et al., 2019). No litoral norte da Bahia, as comunidades pesqueiras compartilham os manguezais com a Vó da Lua, a Caipora e o Zumbi (MAGALHÃES et al., 2014). 
Nos manguezais de Taperaçu-Porto, em Bragança/PA, os moradores convivem com o antropomorfo conhecido como Ataíde (COSTA, 2019). De acordo com esses autores, essas entidades espirituais possuem distinções quanto à forma e atribuições e podem estar associadas à sazonalidade (marcadores temporais) e habitats específicos (marcadores espaciais). O temor em relação a esses seres míticos poderia ser traduzido como uma relação de respeito e reverência ao próprio ecossistema manguezal. Percebe-se, assim, que o sistema de crenças associado à cosmovisão das comunidades pesqueiras desempenha papel regulador na dinâmica do ecossistema, devendo, pois, ser utilizado na elaboração de sistemas de manejo tradicionais. Porém, o avanço da urbanização e a introdução de novas religiões que negam a existência de espíritos da natureza são fatores que podem gerar o processo de aculturação entre os pescadores.

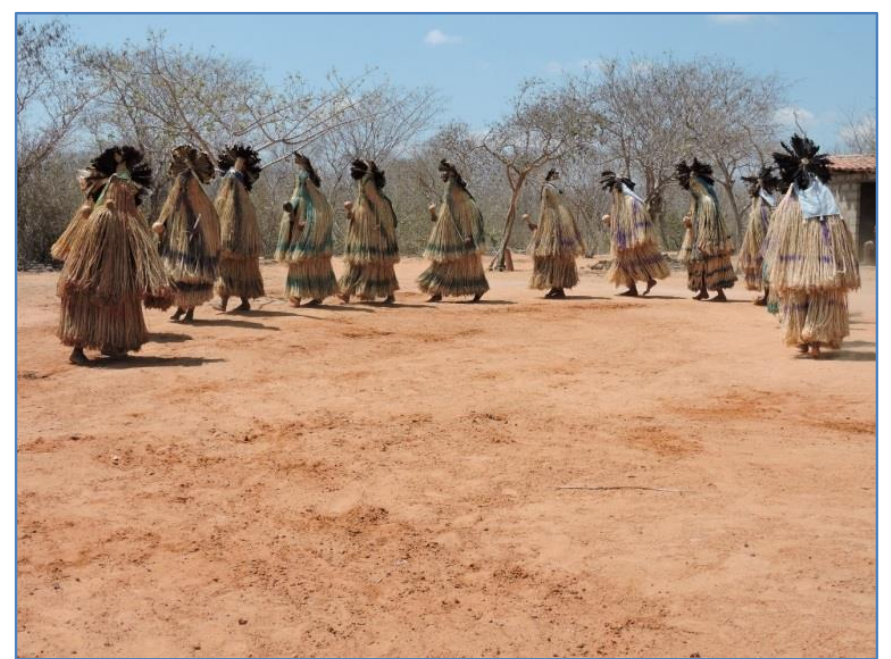

Figura 6. Dança dos Praiás, povo indígena Pankararé. Foto de Alzení de Freitas Tomáz (2017), extraída de Tomáz e Marques (2019).

A floresta (bem como os demais espaços naturais), com sua diversidade de elementos físicos (entidades biológicas) e elementos sutis (entidades espirituais), infunde seu poder espiritual naquele que a sabe penetrar em estado de ternura (MERCIER, 1983). Além disso, cada árvore atua como uma espécie de condensador de energia mágica:

Dríade é uma entidade que vive no interior da árvore, difundindo e repartindo nela suas forças etéreas, e da qual é também uma expressão. Hamadríade, por outro lado, é a entidade que vive no exterior da árvore, que lhe comunica os poderes etéreos exteriores e a protege. Quando a Percepção e o Sentir do homem se unem a essas entidades, elas lhe insuflam uma nova força, que o desperta para o mundo fascinante da Natureza. O arcano do mistério verde e vermelho é aberto. $\mathrm{O}$ espírito se purifica das paixões vulgares e a alma, libertada, remonta à superfície do corpo, infama o sangue de uma intensidade nova e difunde todo o seu maravilhoso poder [...]. (MERCIER, 1983, p. 17).

Árvores Foye [Drimys winteri] são árvores sagradas da vida que conectam os mundos natural, humano e espiritual e permitem que os xamãs Mapuche, ou machi, participem das forças que permeiam o cosmos. (BACIGALUPO, 2007, p. 1).

Em face do que é explicitado nas citações acima e considerando a intrínseca capacidade que temos de nos comunicar com os espíritos das árvores (Figura 7), reiteramos a importância mágicoespiritual dos Seres em Pé:

Ao aproximarmo-nos de uma árvore, aproximamo-nos de um ser sagrado que pode ensinar-nos muito acerca do amor e da dádiva sem fim. As árvores 
fazem parte dos milhões de seres que fornecem o ar, as casas, o combustível e os livros. Trabalhar com o espírito da árvore pode trazer-nos uma energia renovada, uma inspiração poderosa e um profundo sentido de comunhão. (CARR-GOMM, 2008, p. 187).

Deus nos fala em nossa mente. Principalmente se estamos na Natureza. Deus está presente em cada flor e em cada árvore, em cada animal ou pássaro, cristal ou nuvem, oceano e onda. Aproxime-se da natureza - árvore ou colina, rio ou flor - e fale intensamente com o ser Elemental que existe dentro da forma. Depois, observe a reação em sua mente e em seu coração e retribua com amor. (GRZICH, 2011, p. 94).

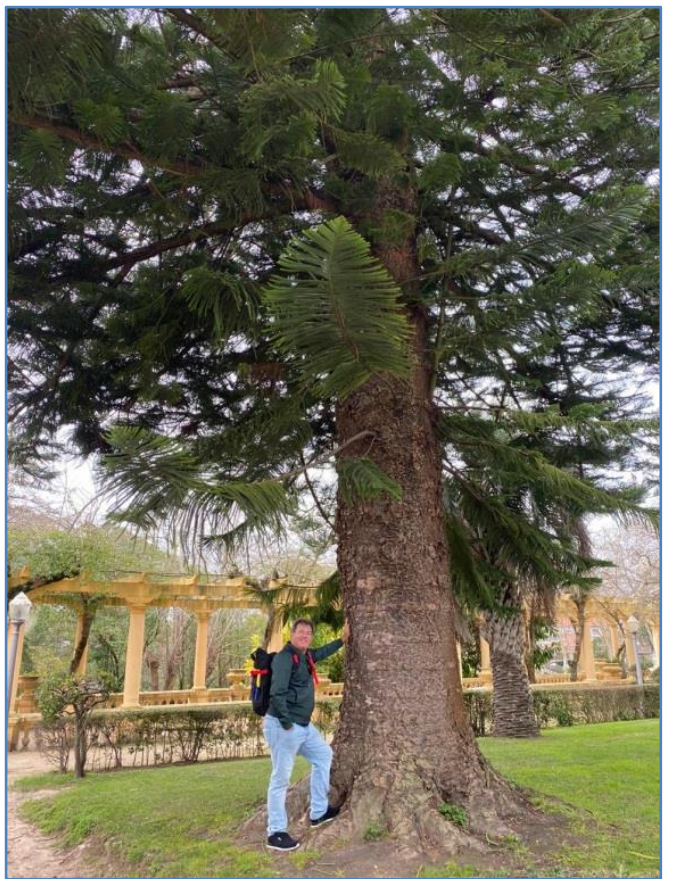

Figura 7. Saudando a uma conífera na cidade de Aveiro, Portugal. Foto de André Nunes da Silva (janeiro de 2020).

A natureza tenta nos demonstrar diariamente que toda forma de vida é capaz de nos ensinar algo. Assim, quando (re)aprendermos a escutar a natureza, conseguiremos demolir nossas percepções debilitadas e descobriremos que a criação mágica é a força vital inerente em todas as coisas (ANDREWS, 2013). Mas as relações com o Grande Mistério não são definidas apenas em termos de como nos relacionamos com o que está fora de nós. Relacionar-se com o sagrado também nos leva ao sentido mais profundo de nós mesmos, ao que é sagrado em nós (devemos ser autorresponsáveis por nossa ecologia interna, nosso self) (RINPOCHE, 2002).

\section{Doença na perspectiva xamânica}

O xamã pode ser visto como importante mediador entre os mundos e tanto pode ajudar a solucionar os problemas dentro de sua comunidade quanto pode auxiliar a pacientes individuais que estejam emocional ou fisicamente enfermos. No entanto, o xamã é uma figura ambígua, pois tanto pode causar danos quanto curar, tratar ou fornecer terapia (para uma discussão sobre "xamanismo negro", relacionado com feitiçaria, consultar a obra de WHITEHEAD e WRIGHT 2004).

De forma muito breve, existem três causas comuns de doença de acordo com o ponto de vista xamânico: 1) a pessoa pode ter perdido seu poder e isso ter-lhe causado depressão, doença crônica ou uma série de infortúnios; 2) a pessoa pode ter perdido parte de sua alma ou essência, levando à perda da alma, que às vezes ocorre durante um trauma físico ou emocional, tais como acidentes, cirurgia, abuso, trauma de guerra, ter passado por um desastre natural etc.; 3) a terceira causa seriam bloqueios espirituais ou energias negativas que alguém tem devido à perda de poder ou alma (INGERMAN, 2008). Nos três casos, os xamãs realizam jornadas específicas ao Inframundo, Mundo Intermediário ou ao Supramundo, auxiliado por espíritos tutelares ou guardiões, em busca de conhecimentos e 
Costa-Neto. Conexões espirituais com a Mãe Terra: plenitude humana manifestada pelo Xamanismo. Ethnoscientia 5, 2020. D.O.I.: 10.22276/ethnoscientia.v5i1.343

informações que possam ajudar na melhora de saúde física, mental, espiritual e emocional de membros de sua comunidade (VITEBSKY, 1997). Uma dessas jornadas é pela busca do Espírito Animal (ver próxima seção) para assim restaurar o poder à pessoa que se encontra desanimada, ou seja, que perdeu sua força animal, encontrando-se deprimida, fraca e predisposta a adoecer (HARNER, 1995). Segundo Harner (op. cit, p. 115):

Os xamãs desde há muito tempo perceberam que o poder do espírito guardião ou tutelar torna a pessoa resistente à doença. A razão é simples: ele propicia um corpo vigoroso que resiste à intrusão de forças exteriores. Do ponto de vista xamânico, num corpo cheio de poder simplesmente não há lugar para a fácil entrada de energias intrusas e prejudiciais, conhecidas, na realidade, como doenças.

O que é cura na perspectiva xamânica? É tudo aquilo que propicia uma conexão maior de cada um de nós com o Grande Mistério e com todas as formas de vida. Isto inclui a transformação do corpo, da mente e do espírito. Também é tudo aquilo que nos propicia aumento do poder pessoal, da força e da capacidade de entendimento. Significa viver na Mãe Terra estando em perfeita harmonia com todo o Universo. Segundo a Tradição Nativa Americana, o indivíduo está curado quando se sente integrado e harmonizado com a natureza e com todas as formas de vida (GRAMACHO e GRAMACHO, 2002). Por essa razão, tudo aquilo que auxilie a curar o corpo, a mente e o espírito é considerado Medicina (SAMS, 1993). Para encontrar uma forma de cura especial, que pudesse responder a um desafio ou a um problema pessoal, os ancestrais de muitas comunidades nativas da América do Norte costumavam caminhar pelas florestas ou sobre os rochedos das montanhas em busca de indicações ou sinais que pudessem auxiliá-los na cura e na sua busca por Sabedoria. Sams (1993) diz que mesmo em nosso mundo agitado de hoje é possível encontrar este Caminho de Cura, se o buscador se dispuser a ler e a entender os sinais da natureza. Interessante registrar, no entanto, que o conceito básico da cura xamânica reside em que "Ninguém cura o outro. A cura já está dentro de cada um" (ABALADA, 2009).

Dada a complexidade das técnicas indígenas que buscam a cura, tratamento ou prevenção de doenças e infortúnios os mais diversos, e reconhecendo-se, hoje, que muito do conhecimento etnomédico indígena que é comercializado nos centros urbanos de todo mundo encontra-se mesclado com terapias e procedimentos oriundos de tradições orientais (yoga, ayurveda) e europeias (naturopatia, aromaterapia), recomenda-se ao leitor procurar conhecer tanto a linha terapêutica xamânica, bem como quem a aplica (seja xamã ou terapeuta holistico).

\section{Espíritos Animais}

O xamã experiente é acompanhado por alinhados ou "ajudantes espirituais", com quem ele se associa quando realiza as viagens xamânicas. Eles podem ser deuses ou ancestrais, mas geralmente são espíritos de animais poderosos, ágeis ou astutos. Frequentemente, eles permitem que o xamã se transforme em uma dessas criaturas ou assuma seus atributos - voar para o céu na forma de um falcão ou mergulhar na água como um peixe (VITEBSKY, 1997). No xamanismo tradicional, o espírito animal não se manifesta fisicamente; pode ter uma presença forte, mas sempre permanece transcendente - um habitante do mundo suprassensível (COTTRELL, 2011).

No Xamanismo tupi-guarani, Tupã Tenondé apresenta-se como um colibri (Figura 8), que é a grande expressão do sagrado para o povo guarani, pois é uma das suas primeiras formas de manifestação - é aquele que vê a totalidade a partir dos mundos sutis do espírito. Ainda hoje é sob essa forma ágil que se apresenta um mensageiro divino - aquele que vem da Morada de Tupã quando quer transmitir uma orientação espiritual importante, ou um sinal de proteção, de presença, de indício de caminho correto (WERÁ, 2016). Portanto, o colibri traz um enredo significativo: o de ser a própria essência divina primeva. Além disso, de acordo com o pensamento guarani, cada ser humano tem sua alma-colibri, que habita na Morada do Coração, que é o território de Tupã (CREMA e WERÁ, 2019). Quando a alma-colibri eleva-se ao apyte, a flor sagrada, que reside um palmo acima da cabeça humana - espaço de Jakaira Ru Ete - inspira e transmite sabedoria profunda (WERÁ, 2016). 


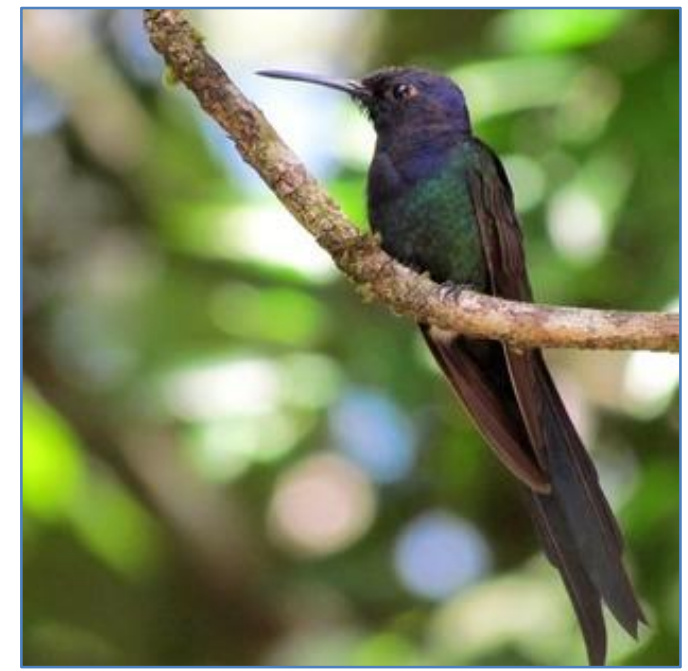

Figura 8. O colibri fala da alegria, da leveza, do amor, simbolizando a capacidade de ter estratégia, flexibilidade, transmutar o denso com alegria e bom humor. Foto de Ana Teresa Galvagne Loss (maio de 2010).

Existem muitos nomes diferentes para os guias animais e isso depende da tradição ou caminho que se segue; muitos deles parecem ser intercambiáveis: Guia espírito animal, Mensageiro, Totem Companheiro, Nagual, Animal guardião, Animal aparentado, Conselheiro, Animal medicina, Aliado, Animal de poder. Um dos principais presentes que os espíritos animais oferecem é a proteção e tutela ao xamã durante tarefas árduas. Esses aliados espirituais também podem ser usados para ajudar a encontrar objetos perdidos, mediar relacionamentos problemáticos e auxiliar na realização de uma determinada meta desafiadora (LEVY e MACHADO, 1995; VAN FEU, 2009; PATTERSON, 2017; GRACE, 2018). Ribeiro (2019) registra que entre os Huaorani da Amazônia equatoriana, por exemplo, o xamã adora um espírito-jaguar e com ele se encontra perigosamente em sonhos - durante o sono ou após ingestão de ayahuasca - para receber orientações sobre caçadas.

Acredita-se que quando nascemos o espírito de ao menos um animal voluntariamente se apresenta para nos proteger e nos guiar por toda nossa vida - nosso animal de poder, nosso totem. Quando alguém é consciente de seu animal de poder é possível se comunicar com ele diretamente e pedir ajuda e guiança dentro de uma jornada xamânica. Mesmo que a pessoa não tenha consciência da presença de seu animal de poder, ele estará lá enviando apoio invisível (ABALADA, 2009; PATTERSON, 2017). Em algumas culturas a descoberta do animal de poder, por meio de um longo retiro na montanha ou na floresta, é uma experiência obrigatória para que todos os jovens nativos possam ser membros integrantes das suas tribos. Segundo Lascariz (2011, p. 73), isso não os prepara para xamãs, mas ajuda-os a tornarem-se indivíduos integrados no sistema ecossocial em que vivem, onde humanos e espíritos interagem regularmente.

De modo geral, os animais de poder são animais selvagens, não domesticados. Os xamãs sentem que os animais domesticados perderam em grande parte seu poder. Eles atendem as pessoas de maneira mais física do que espiritualmente (ARTÉSE, 2001; GRACE, 2018). Há poucas exceções, mas até essas exceções não são outra coisa que um vínculo indireto com o verdadeiro animal de poder. Por exemplo, tem pessoas que possuem o cão ou o gato como totem. Esses animais têm sua própria medicina e poder, mas o animal doméstico pode ser simplesmente o aspecto dócil de seu homólogo selvagem: o cão pode estar vinculado ao lobo, ao coiote ou qualquer outro canídeo, enquanto o gato pode estar associado ao leão, pantera, tigre, onça etc. (ANDREWS, 2013).

É comum ter uma criatura mitológica como animal de poder, como Pégaso ou o Unicórnio. Também se pode ter um animal extinto (dinossauro, por exemplo) como animal de poder, uma vez que o espírito é eterno (ARTÉSE, 2001; PATTERSON, 2017). Todos os animais guias têm um poder enorme e cada um deles tem lições únicas e inesperadas para nos ensinar, como, por exemplo, o esquilo (Figura 9), que traz a ideia de previdência, dando atenção ao que faz e cultivando ações benevolentes, cuidando do hoje para não lhe faltar no futuro; e uma vez que o esquilo sobe e desce das árvores, ele é considerado um mediador entre os diferentes mundos. Um camundongo tem tanto poder quanto um leão, mas cada um deles tem algo bem diferente para nos transmitir (ROCHA et al., 2005).

A energia invocada é a da espécie, daí referir-se à "iluminação e visão da águia", à "coragem do urso", à "força da onça", ou à "astúcia da raposa". As características individuais representam 
espécies e o espírito guardião de uma pessoa é uno com todos os representantes do grupo a que pertence, por exemplo, se alguém tem como guardião o urso significa que ela se alia à energia mágicoespiritual de todos os ursos (GRAMACHO e GRAMACHO, 2002). Estes espíritos guardiões trazem a sua medicina, poder, força e capacidade de cura (SAMS e CARSON, 2000). Assim, lobo e cobra devoram as doenças durante as sessões de cura; urubu é o faxineiro que limpa os resíduos tóxicos emocionais e físicos - de feridas profundas, desta e de outras vidas (ARTÉSE, 2001; JANSSON, 2012). Observando os animais, podemos trazer para nosso íntimo a força deles, imitando sua estratégia para superar as dificuldades em nossas próprias relações pessoais. Por exemplo: em tempos difíceis, eu hibernaria numa caverna como se fosse um urso ou agiria como o castor e construiria novos atalhos e saídas para superar a crise? (WAGNER, 2000).

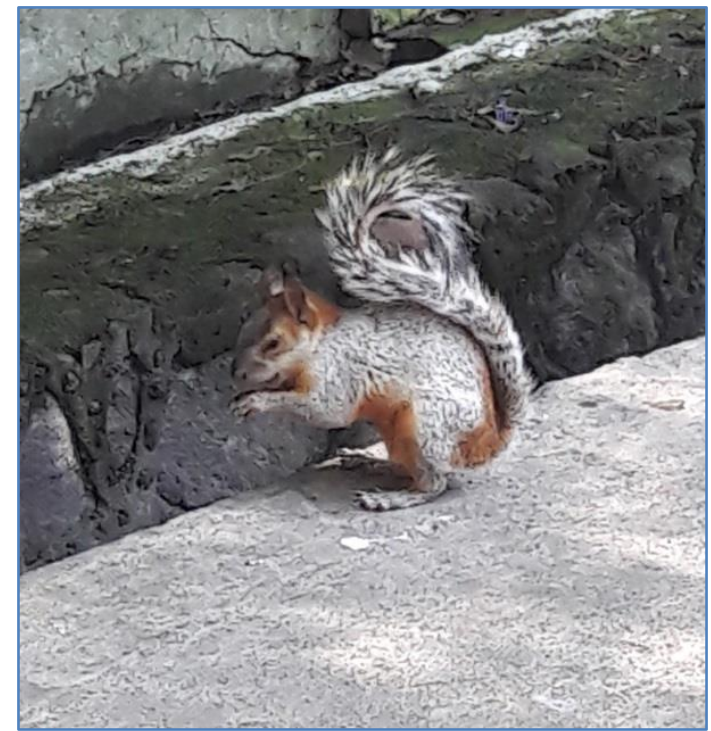

Figura 9. Esquilo, cujo poder simbólico remete à precaução, planejamento e previdência, equilíbrio do dar e receber. Foto do autor (setembro de 2017).

As aves, por exemplo, são mensageiras que nos trazem um entendimento maior de nossos sonhos e visões (MATTIMORE e STAR WOLF, 2018). Ao ver uma ave, reflita sobre a sua cor, a direção de seu voo, se ela gorjeia ou não. Cada uma dessas coisas simples dá à ave mais valor simbólico potencial. Se de algum modo alguém encontra uma pena no caminho (pois no pensamento xamânico nada é ao acaso), deve parar e refletir sobre o significado deste achado: "O que se estava pensando no momento que a pena foi achada? O que está ocorrendo em tua vida no momento? Quais eram teus pensamentos iniciais quando você a viu ou quais palavras vieram à tua cabeça? Quaisquer dessas questões podem ajudar a determinar a razão, ou apenas pode ser um presente para ser usado mais tarde" (ANDREWS, 2013).

Invertebrados, como formigas, abelhas, cigarras borboletas, aranhas e minhocas, podem ser animais de poder, pois são alguns dos seres e professores mais antigos do planeta Terra. Explorando os arquétipos de insetos, aracnídeos e anélidos, Star Wolf e Cariad-Barrett (2013) revelam os padrões de ativação da consciência no voo da abelha, na crisálida transformadora de uma borboleta, nas teias criativas da aranha e na reciclagem alquímica do antigo em novo pela minhoca. Durante a jornada em busca do animal de poder, se alguém perceber enxames ou amontoados desses artrópodes em determinada área do corpo, pode significar que esses animais estejam indicando uma doença (PATTERSON, 2017). Igualmente, cobras, lagartos e dragões quando mostram suas presas e silvam pode ser um sinal de enfermidade. A importante distinção a fazer é se o animal que apareceu está se mostrando como um verdadeiro ajudante. Por exemplo, algumas pessoas possuem uma grande tarântula como animal de poder. No entanto, isso é bem diferente de ver centenas de aranhas amontoadas no fígado de alguém (PATTERSON, op. cit.).

De um modo geral, algumas tradições xamânicas falam que existem quatro tipos de guias animais: mensageiro, jornada, vida e sombra (PATTERSON, 2017). O guia espiritual mensageiro geralmente aparece para orientar ou alertar sobre uma situação específica e fica com a pessoa até que a mensagem seja recebida e o aviso atendido. $\mathrm{O}$ guia espiritual de jornada costuma aparecer quando 
Costa-Neto. Conexões espirituais com a Mãe Terra: plenitude humana manifestada pelo Xamanismo. Ethnoscientia 5, 2020. D.O.I.: 10.22276/ethnoscientia.v5i1.343

alguém chega a uma bifurcação ou quando uma decisão é necessária para mudar o curso do caminho na vida. Este animal permanece ao lado da pessoa até que sua jornada seja concluída. A viagem pode demorar dias, meses ou até anos. Guia do espírito de vida permanece com o indivíduo por toda a sua vida e é um reflexo de quem e do que a pessoa é e de sua constituição espiritual. Neste caso, ela será lembrada por seu guia de seus pontos fortes e habilidades mais íntimas. Pode-se até ter mais de um guia animal de vida e este pode ser um tipo de animal com o qual a pessoa teve uma afinidade quando criança, aquele que se encontra com frequência ao seu redor ou um com o qual a pessoa sempre sonha. Já o guia espiritual das sombras é aquele que testa você. No início, é mais provável que instale medo. Este guia entra na vida de alguém para ensinar-lhe lições sobre as áreas que precisam ser mudadas. Representa os medos internos e continuará reaparecendo até que mudanças positivas sejam feitas (PATTERSON, 2017; GRACE, 2018).

Quando alguém se conecta com seus guias espirituais animais, precisa ter em mente suas características de sobrevivência e o papel que desempenham no ciclo de vida e morte da natureza. Essas características ajudarão a pessoa a crescer, tomar decisões e determinar o rumo de sua vida, como bem expressam Sams e Carson (2000) na passagem abaixo:

"Quando você exorta o poder de um animal, está pedindo para ser envolvido em completa harmonia com a força da essência dessa criatura. Compreender esses irmãos e irmãs é um processo de cura e deve ser abordado com humildade e discernimento. Certos aspectos das lições dadas por essas criaturas foram escolhidas para refletir as lições que todo espírito precisa aprender no Bom Caminho Vermelho. Essas são as lições de ser humano, de ser vulnerável e de buscar a totalidade com tudo o que existe. Elas fazem parte do Caminho para o Poder. O poder reside na sabedoria e na compreensão do papel de cada um no Grande Mistério, e em honrar o fato de que cada ser vivo é um Mestre". (SAMS e CARSON, 2000, p. 25).

\section{Do Antropoceno para o Ecoceno}

No último dia 22 de agosto de 2020, atingimos a marca lamentável de esgotamento ecossistêmico no planeta. O Dia da Sobrecarga da Terra (overshoot day) é o momento em que passamos a demandar mais recursos naturais e serviços ecossistêmico do que a Terra é capaz de regenerar em um ano; isto é, a data registra que atualmente precisamos de 1,6 planeta para suprir toda a nossa demanda de consumo. Devemos todos, enquanto a espécie que determina a existência das demais, repensar nossas escolhas pessoais. Precisamos urgentemente sair da era do Antropoceno ${ }^{7}$ (VIOLA e BASSO, 2016) e entrar na era do Ecoceno (BERRY, 1996). A primeira faz referência ao intervalo temporal geológico presente, no qual condições e processos geologicamente significantes foram, e continuam sendo, profundamente afetados pela atividade humana, enquanto a segunda é o período em que a conduta humana deverá guiar-se pelo ideal de uma comunidade de terra integral, um período quando os seres humanos estarão presentes sobre a Terra de uma forma mutuamente equilibrada com todo o cosmos (VAUGHAN-LEE, 2013).

As práticas xamâmicas (re)surgem e se popularizam no contexto da atual sociedade "pósmoderna", em que um número cada vez maior de pessoas está construindo suas próprias relações espirituais com a Terra, com outros povos e culturas e com outros seres com os quais se partilha o ambiente, como plantas, animais e mesmo seres espirituais (BLAIN, 2002; SCURO, 2018). Neste sentido, Lauren de Boer (2005) enumera os princípios para uma relação sagrada com a Terra viva:

- Relação sagrada em que reconhecemos e honramos o Espírito que nos traz à independência e, ao fazê-lo, vivemos em relações sagradas;

- Evolução consciente onde ativamente exploramos como nós, como indivíduos e como uma espécie, podemos nos mover em direção a um estilo de vida que incorpora relações mutuamente fortalecedoras com todas as formas de vida e sistemas naturais da Terra e, ao fazê-lo, vivemos em conexão e reverência por toda vida;

\footnotetext{
7 Termo cunhado pelo prêmio Nobel em química, o holandês Paul Creutzen, e o biólogo Eugene Stoemer, em 2000 .
} 
- Sabedoria coletiva onde nós honramos a essência das tradições de sabedoria do mundo como fontes importantes para aprender valores de compaixão, reverência e gratidão e, ao fazê-lo, despertamos para uma sabedoria mais profunda e contemporânea;

- Envolver-se em experiências de aprendizado mútuo à medida que criamos uma comunidade da Terra ouvindo e falando do coração e, ao fazê-lo, somos informados pela sabedoria e compaixão uns dos outros;

- Escolha consciente onde reconhecemos que nossas escolhas diárias, mesmo as pequenas e habituais, têm um impacto sobre as espécies da Terra de maneiras benéficas e destrutivas e procuramos promover estilos de vida que levem à justiça social, sustentabilidade e segurança ecológica para toda a vida na Terra e, ao fazê-lo, vivemos com intenção consciente;

- Inclusão onde abraçamos os desafios e as alegrias de pontos de vista e valores verdadeiramente diversos em todas as áreas da vida, a fim de aceitar e compreender melhor a profundidade da experiência de cada um e valorizar a diversidade de vida da Terra e respeitar os direitos de cada espécie expressar-se e, ao fazê-lo, fomentamos e encorajamos os dons únicos uns nos outros e em toda a vida;

- Nós celebramos o papel humano como um agente positivo que aumenta a vida na história da Terra e, ao fazê-lo, vivemos a maravilha e o mistério do Universo vivo.

Quanto mais pessoas estiverem despertas, tendo encontrado a divindade dentro de si, mais sentir-se-ão religadas com a Grande Fonte para que vivam uma vida plena de Paz, Saúde, Harmonia e Abundância. Quando nós, enquanto humanidade, vivenciarmos a união sagrada da Mãe Terra com o Pai Céu, da Ciência com a Espiritualidade, deixando fluir o ritmo natural da Unicidade, passaremos a nos perceber mais empáticos, menos competitivos, entendendo melhor os conceitos de irmandade, comunhão e respeito à vida de todos e de tudo. Depois que alguém passa pela experiência transcendental de ser uno com um espírito sábio e benevolente, ou uma árvore, um animal ou uma rocha, reconhece que tudo é vivo, completo e surpreendente. Não se poderá mais olhar para qualquer ser ou aspecto deste mundo como um objeto a ser usado, pois tudo se torna um sujeito com espírito próprio. A resposta à crise socioambiental e civilizatória requer uma profunda mudança em nossas ações diárias, as quais devem brotar de um profundo sentimento de Amor, Harmonia e Bondade; só assim começaremos a cocriar no mundo como nossa verdadeira natureza espiritual determina.

\section{REFERÊNCIAS}

ABALADA, Dulce Leal. Horóscopos ocultos da natureza: a astrologia dos xamãs, dos druidas e dos alquimistas. Sintra: Zéfiro, 2009.

ALVES, José Jucyêr F. Ecologia e espiritualidade. Kairós - Revista Acadêmica da Prainha, v. 2, p. 428435, 2008 .

ANDREWS, Ted. Animal chamán: la sabiduría y los poderes mágicos y espirituales del mundo animal. Madrid: Arkano Books, 2013.

ARRIEN, Angeles. Las cuatro sendas del chamán. Madrid: Gaia Ediciones, 2015.

ARTÉSE, Léo. O espírito animal: descubra seu animal guardião. São Paulo: Roca, 2001.

BACIGALUPO, Ana Mariella. Shamans of the foye tree: gender, power, and healing among Chilean Mapuche. Austin: University of Texas Press, 2007.

BERRY, Thomas. The ecozoic era. Disponível em: <https://lightparty.com/Visionary/EcozoicEra.html>. Acesso em: 27 ago 2020.

BLAIN, Jenny. Nine worlds of seid-magic: ecstasy and neo-shamanism in North European paganism. Londres: Routledge, 2002.

BOFF, Leonardo. Ecologia: grito da terra, grito dos pobres: dignidade e direito da mãe terra. Petrópolis: Vozes, 2015.

BOFF, Leonardo. Espiritualidade: um caminho para transformação. Rio de Janeiro: Sextante, 2006.

BOFF, Leonardo. Ética da vida. Rio de Janeiro: Sextante, 2005.

CAMPBELL, Joseph. Todos os nomes da deusa. Rio de Janeiro: Rosa dos Ventos, 1997.

CAPRA, Fritjof. A teia da vida: uma nova compreensão científica dos sistemas vivos. São Paulo, SP: Cultrix, 1996.

CARR-GOMM, Philip. Os mistérios dos druidas: sabedoria antiga para o século XXI. Sintra: Zéfiro, 2008.

CARVALHO, Isabel Cristina Moura; STEIL, Carlos Alberto. A sacralização da natureza e a 'naturalização' do sagrado: aportes teóricos para a compreensão dos entrecruzamentos entre saúde, ecologia e espiritualidade. Ambiente \& Sociedade, v. 11, n. 2, p. 289-305, 2008. 
CAVALCANTI, Raíssa. O retorno do conceito do sagrado na ciência. In: TEIXEIRA, Evilázio Francisco Borges; MÜlLER, Marisa Campio; SILVA, Juliana Dors Tigre da (Orgs). Espiritualidade e qualidade de vida. Porto Alegre: EDIPUCRS, 2004. p. 91-104.

CORDOVIL, Daniela. Sexualidade, espiritualidade e conjugalidades na Wicca brasileira. Religião e Sociedade, v. 37, n. 1, p. 85-103, 2017.

COSTA, Myrcéia Carolyne Guimarães. Amazônia cinza: as narrativas orais do mito do Ataíde nas entranhas dos manguezais de Bragança/PA. 2019. 102 f. Dissertação (Linguagens e Saberes na Amazônia) - Universidade Federal do Pará, Bragança, 2019.

COSTA NETO, Eraldo Medeiros. Ecologia espiritual e patrimônio biocultural. Travessias, v. 14, n. 1, p. 1423, 2020.

COTTRELL, Barry. The way beyond the shaman: birthing a new earth consciousness. Londres: Orca Books, 2008.

COTTRELL, Barry. Creature consciousness: the body's power to create a new shamanism. Caduceus, v. 81, p. 13-16, 2011.

CREMA, Roberto; WERÁ, Kaká. A águia e o colibri: Carlos Castañeda e a ancestralidade tupi-guarani trilhas com coração. São Paulo: Tumiak Edições, 2019.

DE BOER, Lauren. Earthlight vision, mission and principles. Earthlight Journal

for Ecological and Spiritual Living, Oakland, n. 52, 2005.

DIAMOND, Jared M. Colapso: como as sociedades humanas escolhem o fracasso ou o sucesso. São Paulo: Record, 2005.

ELIADE, Mircea. Shamanism: archaic techniques of ecstasy. Princeton: Princeton University Press, 1951.

FARLEY, Claire. The New Age and indigenous spirituality: searching for the sacred. Monograph Bachelor

in Arts. School of Media Communication and Culture, Murdoch University, 2010.

FERNANDES SILVA, Carlos Magno L. Ciência ambiecológica: por uma razão espiritualizada. Curitiba: Appris, 2020.

FOTIOU, Eugenia. The globalization of ayahuasca shamanism and the erasure of indigenous shamanism.

Anthropology of Consciousness, v. 27, n. 2, p. 151-179, 2016.

GRACE, Sonja. Dancing with raven and bear: a book of earth medicine and animal magic. Rochester:

Findhorn Press, 2018.

GRAMACHO, Derval; GRAMACHO, Victória. Magia xamânica: roda de cura. São Paulo: Madras, 2002.

GRZICH, Mirna A. Anjos: tudo que você queria saber para entrar em contato agora. São Paulo: Lua de Papel, 2011.

HARNER, Michael. O caminho do xamã: um guia para manter a saúde e desenvolver o poder de curar. São Paulo: Cultrix, 1995.

HARTMANN, Franz. Os elementais: sua natureza e diversas categorias, grupos, gêneros e classes. 1. ed.

São Paulo: Ícone, 2013.

INGERMAN, Sandra. Shamanic journeying: a beginner's guide. Boulder, CO: Sounds True, 2008.

JACKSON, Nigel. O chamado dos velhos deuses: uma introdução à bruxaria tradicional. Sintra: Zéfiro, 2008.

JANSSON, Lora. Power animal retrieval. Shamanism Annual, v. 25, p. 28-30, 2012.

KERR, Sarah. Dreams, rituals, and the creation of sacred objects: an inquiry into a contemporary Western shamanic initiation. 2012. 266 f. Tese (doutorado em Humanidades), California Institute of Integral Studies, San Francisco, 2012.

KING, Serge Kahili. Xamã urbano: manual prático para aplicação do xamanismo havaiano. 1. ed. São

Paulo: Centro de Estudos \& Consciência Editora, 2010.

KRENAK, Ailton. A vida não é útil. São Paulo: Companhia das Letras, 2020.

KRENAK, Ailton. Ideias para adiar o fim do mundo. São Paulo: Companhia das Letras, 2019.

LASCARIZ, Gilberto de. Quando o xamã voava: sonho, erotismo e morte no xamanismo. Sintra: Zéfiro, 2011.

LEVY, Carminha; MACHADO, Álvaro. A sabedoria dos animais: viagens xamânicas e mitológicas. São Paulo: Opera Prima Editorial, 1995.

LISBOA, Gabriel. "Você vai bater tambor?": um estudo da prática de neo-xamanismo na Aldeia Nativa em

Belo Horizonte. Revista Três Pontos, v. 9, n. 2, p. 1-7, 2012.

LIVRAGA, Jorge Angel. Os espíritos da natureza. Lisboa: Nova Acrópole, 2008.

LOVATTO, Patrícia; ALTEMBURG, Shirley; CASALINHO, Hélvio; LOBO, Eduardo A. Ecologia profunda: o despertar para uma educação ambiental complexa. REDES, v. 16, n. 3, p. 122-137, 2011.

MACRAE, Edward. Guiado pela lua: xamanismo e uso ritual da ayahuasca no culto do Santo Daime. São Paulo: Brasiliense, 1992.

MAGALHÃES, Henrique Fernandes; COSTA NETO, Eraldo M.; SCHIAVETTI, Alexandre. Cosmovisão e etnoconservação nos manguezais do município de Conde, litoral norte do estado da Bahia, Brasil. Etnobiología, v. 12, n. 1, p. 23-29, 2014. 
Costa-Neto. Conexões espirituais com a Mãe Terra: plenitude humana manifestada pelo Xamanismo. Ethnoscientia 5, 2020. D.O.I.: 10.22276/ethnoscientia.v5i1.343

MAGNANI, José Guilherme. O xamanismo urbano e a religiosidade contemporânea. Religião e Sociedade, v. 20, n. 2, p. 113-140, 1999.

MARQUES, Juracy. Natureza sagrada: ensaios de ecologia humana. Petrolina: Franciscana, 2012.

MATTIMORE, Carley; STAR WOLF, Linda Sacred messengers of shamanic Africa: Teachings from Zep Tepi, the Land of First Time. Bear \& Company, 2018

MCKENNA, Terence. The food of the gods: the search for the original tree of knowledge. Nova York:

Bantam, 1993.

MERCIER, Mario. Chamanisme et chamans: le vêcu dans l'expérience magique. St-Jean-de-Brave:

Editions Dangles, 1987.

MERCIER, Mario. Iniciação ao xamanismo e à magia natural: a natureza e o sagrado. São Paulo:

Pensamento, 1983

METZNER, Ralph. Ayahuasca: alucinógenos, consciência e o espírito da natureza. Rio de Janeiro: Gryphus, 2002.

MONTGOMERY, Pam. Plant spirit healing: a guide to working with plant consciousness. Rochester: Bear \& Company, 2008.

NAESS, Arne. Los movimientos de la ecología superficial y la ecología profunda: un resumen. Ambiente y Desarrollo, Santiago de Chile, v. 23, n. 1, p. 98-101, 2007.

OLIVEIRA, Karla Cristina Damasceno de; BORGES, Luiz Carlos. Pajelança, meio ambiente e cotidiano: interação dos pajés com a natureza - Cachoeira do Arari/PA. In: SEMINARIO DE INVESTIGACIÓN EN MUSEOLOGÍA DE LOS PAÍSES DE LENGUA PORTUGUESA Y ESPAÑOLA, 2., 2010. Anais... Buenos Aires, 2010. p. 252-262.

PATTERSON, Rachel. Pagan portals - animal magic: working with spirit animal guides. Winchester:

Moon Books, 2017. 2010.

PECK, Steven L. Death and the ecological crisis. Agriculture and human values, v. 27, n. 1, p. 105-109,

PUTOVÁ, Barbora. Prehistoric sorcerers and postmodern furries: anthropological point of view.

International Journal of Sociology and Anthropology, v. 5, n. 7, p. 243-248, 2013.

RAMOS, Denise Gimenez et al. Os animais e a psique: baleia, carneiro, cavalo, elefante, lobo, onça, urso. 2. ed. São Paulo: Summus, 2005.

RIBEIRO, Sidarta. O oráculo da noite: a história e a ciência do sonho. São Paulo: Companhia das Letras, 2019.

RINPOCHE, Tenzin Wangyal. Healing with form, energy and light: the five elements in Tibetan Shamanism, Tantra, and Dzogchen. Ithaca, NY: Snow Lion Publications, 2002.

SAMS, Jamie. As cartas do caminho sagrado: a descoberta do ser através dos ensinamentos dos índios norte-americanos. Rio de Janeiro: Rocco, 1993.

SAMS, Jamie; CARSON, David. Cartas xamânicas: a descoberta do poder através da energia dos animais.

Rio de Janeiro: Rocco, 2000.

SCURO, Juan. (Neo)chamanismo. Aspectos constitutivos y desafíos analíticos. Horizonte Antropológico, n. 51, p. $259-288,2018$.

SHIVA, Vandana. Seed sovereignty, food security: women in the vanguard of the fight against GMOs and corporate agriculture. Berkeley: North Atlantic Books, 2016.

SILVA, André Bastos da et al. Water spirits within the fishers' worldview: implications for fishing management in Northeast Brazil. Journal of Ethnobiology and Ethnomedicine, v. 15, n. 70, 2019.

SMITH, Nigel. Enchanted forest. Natural History, v. 82, n. 8, p. 14-20, 1983.

SOUZA DE PAULA, Samuel. Práticas bioxamânicas: despertar das capacidades interiores. 2. ed. São Paulo: Alfabeto, 2014.

STARHAWK, J. A dança cósmica das feiticeiras: guia de rituais à Grande Deusa. São Paulo: Nova Era, 2003

STAR WOLF, Linda; CARIAD-BARRETT, Anna. Sacred medicine of bee, butterfly, earthworm, and spider: shamanic teachers of the Instar Medicine Wheel. Rochester: Bear \& Company, 2013.

STEINHART, Peter. Ecological saints. Audubon, v. 86, n. 4, p. 8-9, 1984.

STERN, Fábio L. Cosmologia xamânica: a ressignificação do xamanismo na naturologia brasileira. 2019.

235 f. Tese (Doutorado em Ciência da Religião) - Pontifícia Universidade de São Paulo, São Paulo, 2019.

STUTLEY, Margaret. Shamanism: an introduction. Londres: Routledge, 2003.

TOLLE, Eckhart. Um novo mundo: o despertar de uma nova consciência. Rio de Janeiro: Sextante, 2007.

TOMÁZ, Alzení de Freitas; MARQUES, Juracy. O território sagrado Pankararé na ciência do Amaro.

Ethnoscientia, v. 4, p. 1-18, 2019. D.O.I.: 10.22276/ethnoscientia.v4i1.212.

VAN FEU, Eddie. Magia xamânica: despertando seu animal totem. Rio de Janeiro: Linhas Tortas, 2009.

VAUGHAN-LEE, Llewellyn. Spiritual ecology: the cry of the earth. Califórnia: The Golden Sufi Center, 2013 
Costa-Neto. Conexões espirituais com a Mãe Terra: plenitude humana manifestada pelo Xamanismo. Ethnoscientia 5, 2020. D.O.I.:

VIOLA, Eduardo; BASSO, Larissa. O sistema internacional no antropoceno. RBCS, v. 31, n. 92, p. 1-18, 2016

VITEBSKY, Peter. Worlds of the shaman. Natural History, v. 106, n. 2, p. 32-53, 1997.

WAGNER, Valéria Silveira. O poder dos animais: como utilizar a sabedoria dos animais para melhorar nosso dia-a-dia. São Paulo: Editora Gente, 2000 (Série espiritualidade no trabalho).

WERÁ, Kaká. O trovão e o vento: um caminho de evolução pelo xamanismo tupi-guarani. São Paulo: Polar Editorial: Instituto Arapoty, 2016.

WESSELMAN, Hank. A sabedoria do xamã. Rio de Janeiro: Rocco, 2006.

WHITEHEAD, Neil L.; WRIGHT, Robin. In darkness and secrecy: the anthropology of assault sorcery and witchcraft in Amazonia. Durham: Duke University Press, 2004.

WINKELMAN, Michael James. Shaman and other "magico-religious" healers: a cross-cultural study of their origins, nature, and social transformations. Ethos, v. 18, n. 3, p. 308-352, 1990.

WINKELMAN, Michael James. Shamans, priests, and witches: a cross-cultural study of magico-religious practitioners. Tempe: Arizona State University, 1992.

WINKELMAN, Michael James. Shamans. In: DARITY, William A. (ed.). International encyclopedia of the social sciences. 2. ed. Michigan: Macmillan Reference, 2007. p. 486-488.

ZNAMENSKI, Andrei A. The beauty of the primitive: shamanism and the Western imagination. Nova York: Oxford University Press, 2007. 